\title{
The association between duration of breastfeeding and atopy in children with or without family history of atopic disease
}

\author{
Riana Novy, Budi Setiabudiawan, Cissy B. Kartasasmita
}

\begin{abstract}
Background Atopic diseases (AD) are the most common chronic diseases in childhood, and their incidence has a tendency to increase recently. Tendency to have atopy could be triggered by many factors originated in early life, including time of breastfeeding cessation. Objective To determine the association between exclusive and duration of breastfeeding and atopy in children with or without family history of atopic disease.

Methods This was an observational clinical epidemiology study performed at Babakansari, Padasuka, Garuda Primary Health Care Center in Bandung from January to March 2006. One hundred fifty of 749 children were randomized from group with and without family history of AD. They underwent skin prick tests and total serum IgE level analysis. Atopy was defined as a positive skin prick test to any of the eight allergens tested. History of exclusive and duration of breastfeeding was obtained from their parents. Significance tests for contingency tables were on the basis of $\mathrm{x}^{2}$ test for association odds ratio with 95\% confidence interval.

Results Atopy was found in $28.2 \%$ of children, of whom $32.4 \%$ with and $23.9 \%$ without family history of AD. Children exclusively breastfed exhibited a reduced risk of atopy $(5.8 \%$ v $35.3 \%, \mathrm{OR}=0.11$, $95 \% \mathrm{CI}=0.03 ; 0.34, \mathrm{P}<0.001)$. The difference of atopy was strongly significant between children who had exclusive breastfeeding and those without exclusive breastfeeding whether or not the subjects had family history of $\mathrm{AD}(\mathrm{P}<0.001)$. There was a highly significant risk reduction for atopy related to prolonged breastfeeding $(=6$ months) $(\mathrm{OR}=0.37,95 \% \mathrm{CI}=0.19$ to $0.72, \mathrm{P}=0.001)$. The difference of atopy was strongly significant between children who had prolonged breastfeeding and short breastfeeding duration whether or not the subjects had family history of $\mathrm{AD}(\mathrm{P}<0.001)$

Conclusions Exclusive and prolonged breastfeeding decrease atopy in children with as well as without family history of AD. [Paediatr Indones 2007;47:179-184].
\end{abstract}

Keywords: Atopy, atopic disease, total serum $\operatorname{IgE}$, breastfeeding
A topic diseases (AD) are the commonest chronic diseases in childhood, posing serious problems in the world. ${ }^{1,2}$ Their incidence tends to increase recently and their prevalence varies worldwide. ${ }^{1,3,4}$ The prevalence of symptoms of asthma varies from $28 \%$ to $36 \%$ in the industrial countries. ${ }^{5}$ Tendency to get atopy or AD can be triggered by many factors acquired in the early stage of life. These include low birth weight, maternal smoking, and possibly, early cessation of exclusive breastfeeding. ${ }^{6}$ When do environmental factors exert their major effects? There may be a "window of opportunity" in the first few years of life when the developing immune system is particularly susceptible to being directed along an atopic pathway. ${ }^{2,7}$ The maturation of the immune system has been proposed to continue up to 5-7 years of age. ${ }^{8-11}$ Time of exclusive breastfeeding cessation or early exposure to cows' milk and other foreign food proteins which were introduced in the first months of life can increase atopy. ${ }^{12}$ Some studies indicated that prolonged breastfeeding significantly decreased the risk of asthma and other allergic

From The Department of Child Health, Medical School, Padjadjaran University, Hasan Sadikin General Hospital Bandung, Indonesia.

Reprint requests to: Riana Novy E., MD, Department of Child Health, Medical School, Padjadjaran University/Hasan Sadikin General Hospital, Bandung. Jl Pasteur No. 38. Telp. 62-22-2034426. Fax. 62-22-203 5957. 
diseases among children. ${ }^{6,12-16}$ However, other studies have failed to confirm it. ${ }^{17,18}$

Since the scientific evidence about the effect of breastfeeding on the development of allergic disease is inconclusive, especially in Indonesia, a study of this matter is needed. The aim of this study was to determine the association between duration of breastfeeding and atopy in children with or without family history of $\mathrm{AD}$.

\section{Methods}

We performed an observational clinical epidemiology study on groups with and without family history of $\mathrm{AD}$ as a part of "Prevalence of allergic and identification of risk factors in the first two years of life" study at Babakansari, Padasuka, and Garuda Primary Health Care Center in Bandung. The first phase study was a community survey that was done from May to August 2004. The second phase was from January to March 2006. Inclusion criteria were children who had completed phase I study and physically healthy. Those who changed address or consumed first generation antihistamine within three days, non-sedative antihistamine within seven days, or systemic or topical steroids within three weeks before skin prick test procedure were excluded.

From 800 children joining the first phase, only 749 were eligible for the next phase, of whom 204 children had family history of AD. Subjects from those with and without family history of $\mathrm{AD}$ were randomly chosen. Subjects who fulfilled the inclusion criteria were brought to Hasan Sadikin Hospital Bandung. In the hospital, the study procedure was re-explained and written informed consent was obtained. Afterward, history, physical examination, skin prick test, and blood sampling were performed.

Exclusive breastfeeding denoted that the infants were only breastfed and no infant formulas, cow's milk, or solid foods had been introduced except for drugs, vitamin, or oral rehidration solution within six months of life. Duration of breastfeeding was defined as duration during which a child was breastfed (in months), with or without infant formulas, cow's milk, or solid foods, in which was grouped into two categories, i.e., breastfed $<6$ months and breastfed $\geq 6$ months.

Skin prick test was performed in the volar area of the forearms with allergens i.e Dermatophagoides pteronyssinus, Blomia tropicalis, cat hair, cockroach, cow's milk, egg white, peanut, and soyabean. Histamine was used for a positive control and saline for negative control. A test was considered positive if the diameter of skin wheal was $3 \mathrm{~mm}$ or more compared to the negative control at least to one allergen 15 minutes after testing. Atopy was defined as a positive skin prick test to any of the eight allergens tested.

Total serum IgE was measured using electrochemiluminescence immunoassay (ECLIA) methods for quantitative determination of immunoglobulin $\mathrm{E}$ in human serum and plasma, with $<60 \mathrm{IU} / \mathrm{mL}$ as a normal value from reagent package insert for children $1-5$ years of age.

SPSS software version 11.5 for windows and EpiInfo Version 6.0 were used to analyze the data. Significance tests for contingency tables were on the basis of $\chi^{2}$ test for association odds ratio with 95\% confidence interval.

This study was approved by the Health Study Ethical Committee at Medical School, Padjadjaran University/Hasan Sadikin General Hospital Bandung.

\section{Results}

From 300 subjects, nine children had already moved from the address and the parents of seven children refused to be involved in the study, therefore there were only 284 subjects in this study, with 142 children for each group. The subjects characteristics based on family history of AD is seen in Table 1.

Atopy was found in 80 (28.2\%) children. Prevalence of atopy in group with history of $\mathrm{AD}$ was $52 \%$ greater than the other group, however the difference was not statistically significant $(\mathrm{OR}=1.52,95 \% \mathrm{CI}=$ $0.87-2.65, \mathrm{P}=0.113)$. The atopy prevalence based on family history of $\mathrm{AD}$ is described in Table 2 .

Total serum IgE values were obtained from 271 (95.4\%) blood samples. Median total serum IgE of children with family history of atopic disease (131.7 with range 12.12 to $>2,500 \mathrm{IU} / \mathrm{mL}$ ) was higher than those without family history of $\mathrm{AD}$ (105.9 with range 5.22->2,500 IU/mL). Children who had normal and high total serum IgE level were 79 (29.2\%) and 192 (70.8\%), respectively.

Atopy was found in 61 of 192 (31.8\%) children with high total serum IgE level and in 17 of 79 (21.5\%) 
children with normal total serum IgE level. There was no significant difference of atopy between children with high total serum IgE level compared to those with normal total serum IgE level $(\mathrm{P}=0.09) ; \mathrm{OR}(95 \% \mathrm{CI})$ $=1.70(0.88-3.30)$.

Exclusive breastfeeding and non exclusive breastfeeding children percentage were $24.3 \%$ and $75.7 \%$, respectively. There were $76(35.3 \%)$ atopy found in non exclusive breastfeeding, on the other hand only four $(5.8 \%)$ children who exclusively breastfed experienced atopy. There was a high reduction of atopy related to exclusive breastfeeding $(\mathrm{OR}=0.11,95 \% \mathrm{CI}$ $=0.03-0.34, \mathrm{P}<0.001)$. Exclusive breastfeeding was protective factor related to atopy (Table not shown).

The difference of the incidence of atopy was strongly significant between children who had exclusive breastfeeding and those without exclusive breastfeeding whether or not the subjects had family history of $\mathrm{AD}(\mathrm{P}=0.001)$ Exclusive breastfeeding seems to have a preventive effect on atopy with or without family history of AD (Table 3 ).
There were $232(81.7 \%)$ children who had breastfeeding $\geq 6$ months and $52(18.3 \%)$ children who had breastfeeding $<6$ months. Twenty four of $52(46 \%)$ children exposed to a short breastfeeding duration ( $<6$ months) were atopy, compared to 56 of $232(24.1 \%)$ children with prolonged breastfeeding ( $\geq 6$ months).

According to statistical analysis with chi-square calculation, prolonged breastfeeding seems to have preventive effect on atopy $(\mathrm{OR}=0.37,95 \% \mathrm{CI}=0.19$ to $0.72, \mathrm{P}=0.001$ ) (Table not shown).

Based on family history of $\mathrm{AD}$, prolonged breastfeeding was protective factor related to atopy in children with and without family history of $\mathrm{AD}$ $(\mathrm{P}<0.001)$ (Table 4).

\section{Discussion}

Atopy was proven by skin prick test and were found in $28.2 \%$ children, and $32.4 \%$ of them had family history

Table 1. Subjects characteristics based on family history of atopic disease

\begin{tabular}{lccc}
\hline Characteristics & \multicolumn{2}{c}{ Family History of $\begin{array}{c}\text { Atopic Disease } \\
\text { Positive }\end{array}$} & $\begin{array}{c}\mathrm{P} \\
\text { vegative }\end{array}$ \\
\hline Sex & & & \\
$\quad$ Boy & $64(45.1 \%)$ & $66(46.5 \%)$ & 0.81 \\
$\quad$ Girl & $78(54.9 \%)$ & $76(53.5 \%)$ & \\
Age (months) & & & \\
$\quad$ X (SD) & $36.4(1.8)$ & $36.2(1.8)$ & 0.23 \\
Range & $32.1-40.5$ & $32.5-40.2$ & \\
Nutritional Status & $32(22.5 \%)$ & $39(27.5 \%)$ & \\
$\quad$ Underweight & $107(75.4 \%)$ & $101(71.1 \%)$ & 0.99 \\
$\quad$ Well Nourished & $3(2.1 \%)$ & $2(1.4 \%)$ & \\
$\quad$ Overweight & & & \\
\hline
\end{tabular}

Table 2. Atopy based on family history of atopic disease

\begin{tabular}{cccccc}
\hline $\begin{array}{c}\text { Family History of } \\
\text { Atopic Disease }\end{array}$ & $\mathrm{n}$ & $\%$ & $\mathrm{n}$ & $\%$ & $\mathrm{P}$ \\
\hline Positive & 46 & 32.4 & 96 & 67.6 & value \\
\hline Negative & 34 & 23.9 & 108 & 76.1 & 0.11 \\
\hline
\end{tabular}

Note: OR $(95 \% \mathrm{Cl})=1.52(0.87-2.65)$

Table 3. The association between exclusive breastfeeding and atopy based on family history of atopic disease

\begin{tabular}{|c|c|c|c|c|c|}
\hline \multirow{3}{*}{$\begin{array}{c}\text { Exclusive } \\
\text { Breastfeeding }\end{array}$} & \multirow{2}{*}{\multicolumn{4}{|c|}{ Family history of Atopic Disease }} & \multirow{3}{*}{ Significancy } \\
\hline & & & & & \\
\hline & Atopy & Nonatopy & \multicolumn{2}{|r|}{ Nonatopy } & \\
\hline Yes & 3 & 28 & 1 & 37 & $P<0.001$ \\
\hline No & 43 & 68 & 33 & 71 & r \\
\hline
\end{tabular}


Riana Novy et al: Breastfeeding and atopy in children with or without atopy in family

Table 4. The association between duration of breastfeeding and atopy based on family history of atopic disease

\begin{tabular}{|c|c|c|c|c|c|}
\hline \multirow{3}{*}{$\begin{array}{c}\text { Exclusive } \\
\text { Breastfeeding }\end{array}$} & \multicolumn{4}{|c|}{ Family history of Atopic Disease } & \multirow{3}{*}{ Significanc } \\
\hline & \multirow{2}{*}{\multicolumn{2}{|c|}{ (+) Nonatopy }} & \multicolumn{2}{|c|}{$(-)$} & \\
\hline & & & Atopy & Nonatopy & \\
\hline$\geq 6$ months & 34 & 79 & 12 & 97 & $P<0.001$ \\
\hline$<6$ months & 12 & 17 & 22 & 11 & \\
\hline
\end{tabular}

of $\mathrm{AD}$. Atopy is a personal and or familial tendency to become sensitized and produce IgE antibodies in response to ordinary exposures to allergens. ${ }^{19}$ Björksten et al (cited by Koning ${ }^{20}$ ) described that if one of the parents had $\mathrm{AD}$, then there is a $20-40 \%$ risk for their children to have $\mathrm{AD}$. If both parents had $\mathrm{AD}$, then the risk increases to $60-80 \%$, and if the siblings had $\mathrm{AD}$, then the child would have a $20-30 \%$ risk of $\mathrm{AD} .{ }^{20}$ Atopy is found in $39.8 \%$ children if they had an atopic mother and $30.2 \%$ if their father had AD. In this study we found 34 (23.9\%) from 142 children without family history of $\mathrm{AD}$ were atopy. If there were no atopic parents, then the risk to become atopic was $10 \% .{ }^{21}$ However, Alford et al ${ }^{21}$ described that children without family history of AD had almost 30\% risk to have atopy. Our study revealed no statistically significant difference related to family history of $\mathrm{AD}$. Data on family history of $\mathrm{AD}$ were probably not very accurate since it based only on history without any further test, such as total and specific IgE or skin prick test to family member suspected to have history of AD. Moreover, because most of the parents' education was as low as elementary and junior high schools, they did not fully understand about atopic manifestation. Some of them might just deny of having $\mathrm{AD}$, and this was one of the shortcomings in the study.

Based on package insert of reagent used to determine total serum IgE level, cut off point for 1-5 years old was $60 \mathrm{IU} / \mathrm{mL}$. There were $70.8 \%$ children with high total serum IgE level. Total serum IgE level was influenced by race and genetic factors. Racial factors influence serum IgE level. Orgal et al (cited by Yunginger ${ }^{22}$ ) studied 27 Filipino and 24 white children born and raised in the United States. In the Filipino children, both incidence of $\mathrm{AD}$ were significantly higher than in white children. No significant relationship between high total serum IgE level and atopy $(\mathrm{P}=0.090)$. Total serum IgE level does not always mean that there are atopy, since IgE responds not only to allergen, but also to parasitic infection such as helminthes which can induce Th2. ${ }^{23}$ However, IgE has a major role in allergic responses, thus it has a good correlation with atopy or AD. There is a high significant difference of atopy between exclusively breastfed and non exclusively breastfed $(\mathrm{P}<0.001)^{24}$. Exclusive breastfeeding exhibited a reduced risk of atopy in children with or without family history of AD. Prospective cohort study suggested that skin prick test will be positive significantly in children who had been introduced to formula feeding before the age of four months. ${ }^{6}$ The incidence of atopic dermatitis in infants aged 6-12 months was significantly lower in those who had exclusive breastfeeding for at least four months compared with those without history of breastfeeding. ${ }^{24}$ Infant who had exclusive breastfeeding during four months or more exhibited a reduced risk of asthma and wheezing. ${ }^{12}$ Breast milk may provide direct protection against allergic sensitization through decreased exposure to food antigens, by enhancing maturation of the intestinal mucosal barrier and via immunoglobulin (Ig), such as secretory $\operatorname{IgA}$, secreted in the milk. ${ }^{16}$ Secretory IgA predominates in breast milk and plays a vital role in the provision of local protection to the mucosal membrane. ${ }^{25}$

Children who were breastfed $\geq 6$ months had significantly less risk of atopy compared to those who were breastfed $<6$ months. Although the study did not directly investigated the association between duration of the breastfeeding and atopy, many other researchers found correlations between duration of breastfeeding and atopy. There was a significant risk reduction for asthma related to partial breastfeeding during six months or more. ${ }^{12}$ A cross-sectional, questionnaire-based survey in South Africa, found protective effect of prolonged breastfeeding on the development of allergic disease, particularly hay fever in children born to non allergic parents. ${ }^{16}$ When this was correlated with family history of $\mathrm{AD}$, it seemed that the association between duration of breastfeeding and atopy was significant in children with and without family history of AD. 
Riana Novy et al: Breastfeeding and atopy in children with or without atopy in family

Our results showed that atopy was influenced by environmental factors, i.e., exclusive and duration of breastfeeding.

\section{Conclusion}

Our results indicate that exclusive breastfeeding for at least six months is strongly significant in reducing the risk of childhood atopy. Prolonged breastfeeding may help to reduce the risk of atopy in children with and without family history of AD.

\section{Acknowledgments}

We would especially like to thank all children and parents who participated in this study. We also grateful to the chief of Garuda, Padasuka, Babakansari Primary Health Care Centers, all midwifes for making this study possible.

\section{References}

1. ISAAC. Worldwide variations in the prevalence of asthma symptoms: the International Study of Asthma and Allergies in Childhood. Eur Respir J 1998;12:1225-32.

2. Gold MS, Kemp AS. Atopic disease in childhood. MJA 2005;182:298-304.

3. ETAC Study Group. Determinant of total and specific IgE in infants with dermatitis. Pediatr Allergy Immunol 1997;8:177-84.

4. Wang XS, Goh DYT, Lynette PCS, Baratawidjaja K, Kartasasmita C, Darwis A, et al. Affluence and asthma, evidence from South East Asia. J World Allergy Org 2005;17:53-7.

5. Bauman A. Latest statistical trends. Cited 2005 Dec 27.Available from: url: http//www.nationalasthma.org.au/.

6. Oddy WH, Holt PG, Sly PD, Read AW, Landau LI, Stanley FJ, et al. Association between breast feeding and asthma in 6 year old children: finding of a prospective birth cohort study. BMJ 1999;319:815-9.

7. Savelkoul HFJ, Neijens HJ. Immune responses during allergic sensitization and the development of atopy. Allergy 2000;55:989-97.

8. Von Hertzen LC. The hygiene hypothesis in the development of atopy and asthma-still a matter of controversy?. Q J Med 1998;91:767-71.

9. Martinez FD, Holt PG. Role of microbial burden in aetiology of allergy and asthma. Lancet 1999;354:1215.
10. Holt PG, Jones CA. The development of the immune system during pregnancy and early life. Allergy 2000;55:68897.

11. Bager P, Westergaard T, Rostgaard K, Hjalgrim H, Melbye M. Age at childhood infections and risk of atopy. Thorax 2002;57:379-82.

12. Kull I, Wickman, M, Lilja G, Nordvall SL, Pershagen G. Breast feeding and allergic diseases in infants-a prospective birth cohort study. Arch Dis Child 2002;87:478-81.

13. Saarinen UM, Kajosaari M. Breastfeeding as profilaxis against atopic disease: prospective follow-up study until 17 years old. Lancet 1995;346:1065-9.

14. Chandra RK. Five-year follow-up of high-risk infants with family history of allergy who were exclusively breast-fed or fed partial whey hydrolysate, soy, and conventional cow's milk formulas. J Pediatr Gastroenterol Nutr 1997;24:380-8.

15. Wright AL, Holberg CJ, Taussig LM, Martinez FD. Factors influencing the relation of infant feeding to asthma and recurrent wheeze in childhood. Thorax 2001;56:192-7.

16. Obihara CC, Marais BJ, Gie RP, Potter P, Bateman ED, Lombard CJ, et al. The association of prolonged brestfeeding and allergic disease in poor urban children. Eur Respir J 2005;25:970-7.

17. De Jong MH, Scharp-van der Linden VTM, Aalberse RC, Oosting J, Tijssen JGP, De Groot CJ. Randomised controlled trial of brief neonatal exposure to cow's milk on the development of atopy. Arch Dis Child 1998;79:126-30.

18. De Jong MH, Scharp-van der Linden VTM, Aalberse RC, Heymans HSA, Brunekreef B. The effect of brief neonatal exposure to cows'milk on atopic symptoms up to age 5. Arch Dis Child 2002;86:365-9.

19. Johansson SGO, Bieber T, Dahl R, Friedmann, PS, Lanier $\mathrm{BQ}$, Lockey RF, et al. Revised nomenclature for allergy for global use: Report of the Nomenclature Review Committee of the World Allergy Organization. J Allergy Clin Immunol 2004;113:832-6.

20. Koning H, Baert MRM, Oranje AP, Savelkoul HFJ, Neijens HJ. Development of immune functions, related to allergic mechanism, in young children. Pediatr Research 1996; 40:363-75.

21. Alford SH, Zoratti E, Peterson EL, Maliarik M, Ownby DR, Johnson CC. Parental history of atopic disease: Disease pattern and risk of pediatric atopy in offspring. J Allergy Clin Immunol 2004;114:1046-50.

22. Yunginger JW. Clinical significance of IgE. In: Middleton E, Reed CE, Ellis EF, Adkinson NF, Yunginger JW, editors. Allergy: principles and practice. $3^{\text {th }} \mathrm{ed}$. Toronto: CV Mosby 
Riana Novy et al: Breastfeeding and atopy in children with or without atopy in family

Company; 1988. p. 849-60.

23. Arshad SH, Tariq SM, Matthews S, Hakim E. Sensitization to common allergens and its association with allergic disorders at age 4 years: a whole population birth cohort study. Pediatrics 2001;108:1-8.

24. Djunaedi T. Manfaat pemberian ASI eksklusif minimal sampai usia 4 bulan terhadap kejadian dermatitis atopik pada bayi usia 6-12 bulan pengunjung unit rawat jalan anak RSUP dr. Hasan Sadikin Bandung. [Thesis]. Bandung: Universitas Padjadjaran; 1998.

25. Leung AKC, Sauve RS. Breast is the best for babies. J National Med Association 2005;97:1010-9. 